\title{
TOXIC EFFECT IN THE LUNGS OF RATS AFTER INHALATION EXPOSURE TO BENZALKONIUM CHLORIDE
}

\author{
RADOSŁAW ŚWIERCZ, TADEUSZ HAŁATEK, JAN STETKIEWICZ, \\ WOJCIECH WĄSOWICZ, BARBARA KUR, ZOFIA GRZELIŃSKA, \\ and WANDA MAJCHEREK
}

Nofer Institute of Occupational Medicine, Łódź, Poland

Department of Toxicology and Carcinogenesis

\begin{abstract}
Background: Benzalkonium chloride (BAC) is a quaternary ammonium compound (QAC) toxic to microorganisms. Inhalation is one of the major possible routes of human exposure to BAC. Materials and Methods: Experiments were performed on female Wistar rats. The rats were exposed to aerosol of BAC water solution at the target concentration of 0 (control group) and $35 \mathrm{mg} / \mathrm{m}^{3}$ for 5 days $(6 \mathrm{~h} /$ day) and, after a 2-week interval, the animals were challenged (day 21$)$ with BAC aerosol at the target concentration of 0 (control group) and $35 \mathrm{mg} / \mathrm{m}^{3}$ for $6 \mathrm{~h}$. Results: Compared to the controls, the animals exposed to BAC aerosol were characterized by lower food intake and their body weight was significantly smaller. As regards BAC-exposed group, a significant increase was noted in relative lung mass, total protein concentration, and MIP-2 in BALF both directly after the termination of the exposure and $18 \mathrm{~h}$ afterwards. Significantly higher IL- 6 and IgE concentrations in BALF and a decrease in the CC16 concentration in BALF were found in the exposed group immediately after the exposure. The leukocyte count in BALF was significantly higher in the animals exposed to BAC aerosol compared to the controls. In the lungs of rats exposed to BAC the following effects were observed: minimal perivascular, interstitial edema, focal aggregates of alveolar macrophages, interstitial mononuclear cell infiltrations, thickened alveolar septa and marginal lipoproteinosis. Conclusion: Inhalation of BAC induced a strong inflammatory response and a damage to the blood-air barrier. Reduced concentrations of $\mathrm{CC16}$, which is an immunosuppressive and anti-inflammatory protein, in combination with increased IgE concentrations in BALF may be indicative of the immuno-inflammatory response in the animals exposed to BAC aerosol by inhalation. Histopathological examinations of tissue samples from the BAC-exposed rats revealed a number of pathological changes found only in the lungs.
\end{abstract}

Key words:

Benzalkonium chloride, Rats, Inhalation, Lungs, Biomarkers, Histopathological examinations

Financial support from the State Committee for Scientific Research (Komitet Badań Naukowych, Warszawa, Poland), Project No. 2P05D 05728 is gratefully acknowledged. This research was supported under the statutory activities of the Nofer Institute of Occupational Medicine IMP grant 1.1. Project manager: Radosław Swiercz, Ph.D. Received: November 6, 2012. Accepted: September 3, 2013.

Corresponding author: R. Świercz, Department of Toxicology and Carcinogenesis, Nofer Institute of Occupational Medicine, św. Teresy 8, 91-348 Łódź, Poland (e-mail: radek@imp.lodz.pl). 


\section{INTRODUCTION}

Benzalkonium chloride (BAC) belongs to the group of quaternary ammonium compounds (QAC). In recent years, numerous works have been published describing the toxic activity of $\mathrm{BAC}$ in the in vitro and in vivo studies [1-13]. Scientific interest in BAC toxicity to the living organisms has resulted from a wide range of its use as a bactericide and preservative. It has been found that BAC used as a component of eye drops may adversely affect the different structures of the eye [1,2,5,7-10]. The widespread use of BAC also involves utilization of its bactericidal activity in the treatment of teeth [14] and the development of new nanocomposite structures with a builtin BAC molecule [15].

In some cases, the use of a BAC-containing product for its intended purpose caused a severe allergic reaction of the skin [16] and eye conjunctiva [17]. There are a number of reports of accidental exposure of humans to BAC, which led to death or a serious injury [18-20].

A major route of human exposure to this toxic compound is inhalation. Inhalation exposure of humans to preparations which include $\mathrm{BAC}$ results from the widespread use of BAC in various nasal sprays [21,22]. It was also found that BAC may play a role in occupational exposure [23].

In recent years, it has been demonstrated that BAC may cause an increased immune response in mice. The authors suggest that the exposure by inhalation can result in an increased risk of allergy caused by BAC [24]. In an inhalation study performed in mice, it was found that inhalation of BAC at higher concentrations induced deep lung effects and also lung inflammation [25].

In previous years we assessed toxic effects of BAC to the respiratory system and changes in the concentrations of catecholamines in the brain of rats exposed by inhalation to BAC aerosol [26,27]. The present study is an extension of our earlier works assessing the toxic effects of exposure to aerosol of BAC water solution in laboratory animals under conditions of repeated inhalation exposure.

\section{MATERIALS AND METHODS}

\section{Animals}

Female NIOM outbred Wist Wistar rats aged from 2 to 3 months obtained from the breeding farm of the Nofer Institute of Occupational Medicine, Łódź, Poland, were used in the experiment.

\section{Chemicals}

The animals were exposed in exposure chambers to Fluka BAC (CAS No. 8001-54-5, purity $\geq 95 \%$ ) aerosol.

\section{Inhalation exposure and experimental design}

The chemical to be tested was injected to the exposure chamber with dynamic air flow to ensure 15 air changes per hour, where rat's head/nose was exposed to a direct contact with the BAC aerosol. BAC was injected into the chamber in the form of aqueous aerosol. The BAC concentration in the chamber was monitored by HPLC [26,28].

The Local Ethics Committee for Experiments on Animals approved the study protocol (Opinion No. Ł/BD/247). Figure 1 is a schematic representation of the experimental protocol. Rats were exposed to BAC aerosol at the target concentration of 0 (control group) and $35 \mathrm{mg} / \mathrm{m}^{3}$ for 5 days $(6 \mathrm{~h} /$ day $)$ and, after a 2-week interval, the animals were challenged (day 21) with BAC aerosol at the target concentration of 0 (control group) and $35 \mathrm{mg} / \mathrm{m}^{3}$ for $6 \mathrm{~h}$. Body weights and food intakes were measured weekly. The animals were given standard laboratory food and water ad libitum, except for the time during which they were exposed to BAC aerosol in the dynamic inhalation chambers. The chamber relative temperature and humidity were maintained at $20-22^{\circ} \mathrm{C}$ and $35-45 \%$, respectively.

Biological materials were collected from the exposed and control animals at two time-points: immediately after termination of exposure (day 21) and $18 \mathrm{~h}$ after the BAC challenge inhalation ended (Figure 1). The rats were 


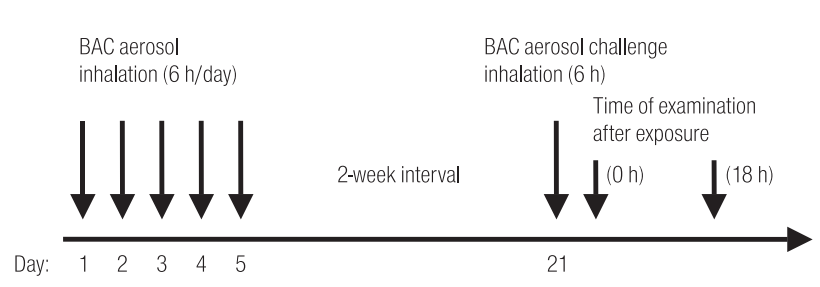

Fig. 1. Schematic diagram of the experimental protocol

anesthetized by an intraperitoneal injection of pentobarbital sodium at $50 \mathrm{mg} / \mathrm{kg}$ body weight and their lungs were lavaged with $2 \times 5 \mathrm{ml}$ of $0.9 \% \mathrm{NaCl}$ solution. Bronchoalveolar lavage fluid (BALF) was collected and centrifuged at $200 \mathrm{~g}$ for $10 \mathrm{~min}$ at $4^{\circ} \mathrm{C}$. The supernatant of BALF was used for biochemistry. Clara cell protein (CC16) was determined with the use of latex immunoassay [29]. Specific rabbit antibodies against $\mathrm{CC} 16$ and a standard for $\mathrm{CC} 16$, based on the purified protein, were obtained as described earlier [30]. Hyaluronic acid (HA) was measured in nonconcentrated BALF by enzymatic-immunoassay (ELISA) kit, including hyaluronic acid binding protein (HABP) capture molecule, Chungai-test (Japan). Lactate dehydrogenase (LDH) activity [31] and levels of matrix metalloproteinase-9 (MMP-9) (Calibrochem), tumor necrosis factor (TNF- $\alpha$ ), interleukin 6 (IL-6), macrophage inflammatory protein (MIP)-2 (Biosource) and total IgE (Bethyl) were measured in BALF (IgE BALF) and serum (IgE-S) using the ELISA kit. GSH-S-transferase (GST) (EC. 2.5.1.18) in postmitochondrial supernatants of rat lung samples was assessed with 1-chloro-2,4-dinitrobenzene (CDNB) [32]. The quantity of CDNB (nmol) reacting during 1 min was assumed to be a unit $(\mathrm{u})$.

The total and differential cell numbers were measured using standard procedures. Lymphocytes, neutrophils and macrophages were counted $(\%)$ under microscope in sediment cells from BALF after staining them with Giemsa and May-Grünwald reagents. For the estimation of leukocytes, sediment cells from BALF were suspended in PBS treated with Türk reagents and counted by optical microscopy in a Bürker chamber. Viability (\%) was estimated for 100 cells after staining the samples with trypan blue.

The necropsy was performed in all animals. Lungs, liver, spleen and kidneys removed during necropsy were fixed in $10 \%$ phosphate-buffered formalin, processed for embedding in paraffin, sectioned and stained with hematoxylin and eosin according to the van Gieson's method.

\section{Statistical analysis}

Statistical analysis was performed with the use of the Kruskall-Wallis test extended with all pairwise comparisons (STATISTICA.PL). Differences were regarded as significant when the probability of the null hypothesis was $<0.05$.

\section{RESULTS}

All animals exposed to BAC aerosol at ca. $35 \mathrm{mg} / \mathrm{m}^{3}$ survived the inhalation exposure. Table 1 shows true BAC aerosol concentration in exposure chamber atmosphere, mean body weight and food intake during the experiment. At all measurement time points (day 7, 14 and 21 of the experiment), food intake and body weight of the animals exposed to BAC aerosol were significantly lower compared to the controls. The reduction of food intake and body mass in the BAC-exposed animals was particularly evident during the first week of the experiment: the corresponding values were ca. $64 \%$ and $22 \%$ compared to the controls, respectively. During the 2nd and 3rd week, the rats exposed to BAC aerosol consumed ca. $28 \%$ and $18 \%$ less food, and their body weight was ca. $11 \%$ and $10 \%$ lower compared to the controls, respectively. Macroscopic examinations did not reveal any significant changes between the controls and the exposed animals. A significant reduction of the absolute liver mass was recorded in all rats exposed to BAC aerosol compared to the control group. A significant increase of the absolute and relative mass of the lungs was noted in 
Table 1. Body weight and food intake parameters in study groups

\begin{tabular}{lcc}
\hline \multicolumn{1}{c}{ Parameters } & $\begin{array}{c}\text { Control group } \\
(\mathrm{N}=7)\end{array}$ & $\begin{array}{c}\text { Exposed group } \\
(\mathrm{N}=10)\end{array}$ \\
\hline $\begin{array}{l}\text { Concentration of BAC }\left(\mathrm{mg} / \mathrm{m}^{3}\right), \mathrm{M} \pm \mathrm{SD} \\
\text { Body weight }(\mathrm{g}), \mathrm{M} \pm \mathrm{SD}\end{array}$ & 0 & $35.4 \pm 6.3$ \\
day 1 of measurement & $162 \pm 4.5$ & $170 \pm 10.4$ \\
day 7 of measurement & $205 \pm 5.0$ & $160 \pm 13.5^{* * *}$ \\
day 14 of measurement & $225 \pm 8.7$ & $201 \pm 13.5^{* *}$ \\
day 21 of measurement & $220 \pm 14.1$ & $199 \pm 13.4^{*}$ \\
Food intake (g/rat/week), M & & \\
day 1 of measurement & - & - \\
day 7 of measurement & 124 & 45 \\
day 14 of measurement & 133 & 95 \\
day 21 of measurement & 120 & 98 \\
\hline
\end{tabular}

M - mean; SD - standard deviation.

$*, * *, * * *$ Significantly different from the control group at $\mathrm{p}<0.05, \mathrm{p}<0.01$ and $\mathrm{p}<0.001$, respectively.

the group of animals exposed to BAC aerosol compared to the controls.

Table 2 shows the changes in the lung weight $/ 100 \mathrm{~g}$ b.w. as well as GST in the lung samples and IgE in serum and other biomarkers in BALF of the rats exposed to BAC aerosol in relation to the control group. As regards BAC-exposed group, a significant increase was noted in the relative lung mass, total protein concentration, and MIP-2 in BALF, both directly after the termination of the exposure and $18 \mathrm{~h}$ afterwards. Significantly higher IL-6 and IgE concentrations in BALF and a decrease in the CC16 concentration in BALF were found in the exposed group immediately after the exposure. No significant differences were noted for HA, GST, MMP-9 and TNF- $\alpha$ in BALF and IgE-S levels between the exposed group and the controls.

Table 3 specifies cellular characterization of BALF data concerning the control group and the rats exposed to BAC aerosol. Leukocyte count in BALF was significantly higher in the exposed animals compared to the controls. No significant differences were noted in the

Table 2. Comparison of examined parameters in study groups at different time points

\begin{tabular}{|c|c|c|c|}
\hline \multirow[b]{2}{*}{ Parameters } & \multirow{2}{*}{$\begin{array}{l}\text { Control } \\
(\mathrm{N}=7)\end{array}$} & \multicolumn{2}{|c|}{ Exposed group } \\
\hline & & $\begin{array}{l}\text { time point }(0 \mathrm{~h}) \\
\quad(\mathrm{N}=5)\end{array}$ & $\begin{array}{l}\text { time point }(18 \mathrm{~h}) \\
\quad(\mathrm{N}=5)\end{array}$ \\
\hline Body weight (g) & $220.00 \pm 14.10$ & $203.00 \pm 6.70^{*}$ & $196.00 \pm 18.20^{*}$ \\
\hline Lung weight/100 g b.w. & $0.66 \pm 0.12$ & $0.96 \pm 0.11^{* *}$ & $0.89 \pm 0.13^{*}$ \\
\hline Total protein $(\mathrm{g} / \mathrm{l})$ & $0.31 \pm 0.22$ & $4.52 \pm 1.91^{* *}$ & $3.29 \pm 1.93^{*}$ \\
\hline $\mathrm{CC} 16$ (mg/l) & $7.73 \pm 1.25$ & $4.28 \pm 2.25^{*}$ & $5.96 \pm 1.29$ \\
\hline
\end{tabular}


Table 2. Comparison of examined parameters in study groups at different time points - cont.

\begin{tabular}{lccc}
\hline & & \multicolumn{2}{c}{ Exposed group } \\
\cline { 3 - 4 } \multicolumn{1}{c}{ Parameters } & $\begin{array}{c}\text { Control } \\
\text { (N = 7) }\end{array}$ & $\begin{array}{c}\text { time point }(0 \mathrm{~h}) \\
(\mathrm{N}=5)\end{array}$ & $\begin{array}{c}\text { time point }(18 \mathrm{~h}) \\
(\mathrm{N}=5)\end{array}$ \\
\hline HA $(\mu \mathrm{g} / \mathrm{l})$ & $6.60 \pm 4.19$ & $11.83 \pm 10.09$ & $4.35 \pm 5.87$ \\
$\mathrm{LDH}(\mathrm{U} / \mathrm{l})$ & $151.60 \pm 58.60$ & $321.40 \pm 94.90^{* *}$ & $217.00 \pm 77.00$ \\
MMP-9 $(\mathrm{ng} / \mathrm{ml})$ & $0.79 \pm 0.05$ & $0.78 \pm 0.09$ & $0.77 \pm 0.05$ \\
TNF- $\alpha(\mathrm{pg} / \mathrm{ml})$ & $29.30 \pm 20.40$ & $38.80 \pm 41.10$ & $23.60 \pm 15.50$ \\
IL-6 $(\mathrm{pg} / \mathrm{ml})$ & $71.20 \pm 69.30$ & $837.60 \pm 601.10^{* *}$ & $496.40 \pm 670.40$ \\
MIP-2 $(\mathrm{pg} / \mathrm{ml})$ & $248.10 \pm 56.90$ & $608.60 \pm 138.30^{* * *}$ & $376.60 \pm 48.30^{*}$ \\
IgE BALF $(\mathrm{ng} / \mathrm{ml})$ & $5.34 \pm 4.21$ & $71.36 \pm 98.60^{*}$ & $15.10 \pm 26.80$ \\
IgE-S $(\mathrm{ng} / \mathrm{ml})$ & $140.80 \pm 48.20$ & $128.20 \pm 6.30$ & $162.80 \pm 29.30$ \\
GST $(\mathrm{u} / \mathrm{mg} \mathrm{protein})$ & $125.60 \pm 53.90$ & $164.10 \pm 107.50$ & $65.40 \pm 36.00$ \\
\hline
\end{tabular}

CC16 - Clara cell protein; HA - hyaluronic acid; LDH - lactate dehydrogenase; MMP-9 - matrix metalloproteinase 9; TNF- $\alpha$ - tumor necrosis factor $\alpha$; IL-6 - interleukin 6; MIP-2 - macrophage inflammatory protein 2; IgE BALF - immunoglobulin E in bronchoalveolar lavage fluid; IgE-S - immunoglobulin E in serum; GST - glutathione $S$-transferase.

$* * * * * *$ Significantly different from the control group at $\mathrm{p}<0.05, \mathrm{p}<0.01$ and $\mathrm{p}<0.001$, respectively.

Results expressed as a mean \pm standard deviation.

Table 3. Bronchoalveolar lavage fluid (BALF) parameters in both study groups

\begin{tabular}{lccc}
\hline \multirow{2}{*}{\multicolumn{1}{c}{ Parameter }} & Control & \multicolumn{2}{c}{ Exposed group } \\
\cline { 3 - 4 } & $(\mathrm{N}=7)$ & $\begin{array}{c}\text { time point }(0 \mathrm{~h}) \\
(\mathrm{N}=5)\end{array}$ & $\begin{array}{c}\text { time point }(0 \mathrm{~h}) \\
(\mathrm{N}=5)\end{array}$ \\
\hline Leukocytes $\left(\times 10^{3} / \mathrm{mm}^{3}\right)$ & $1.74 \pm 0.73$ & $3.64 \pm 2.03$ & $5.56 \pm 4.69^{*}$ \\
Viability $(\%)$ & $97.00 \pm 0.60$ & $97.20 \pm 0.50$ & $97.60 \pm 0.60$ \\
Macrophages $(\%)$ & $93.00 \pm 0.00$ & $75.60 \pm 24.00$ & $87.80 \pm 8.40$ \\
Neutrophils $(\%)$ & $7.00 \pm 0.00$ & $24.40 \pm 24.00$ & $11.60 \pm 8.40$ \\
Lymphocytes $(\%)$ & $0.00 \pm 0.00$ & $1.80 \pm 4.00$ & $0.60 \pm 0.90$ \\
\hline
\end{tabular}

* Significantly different from the control group at $\mathrm{p}<0.05$.

Results expressed as a mean \pm standard deviation.

number of macrophages, neutrophils, lymphocytes or the viability of cells from BALF between the control and the exposed rats.

No signs of histopathological changes were observed in the liver, kidneys and spleen of rats. Photo 1 shows a typical lung of a control rat and the changes in the lungs of the rats exposed to BAC aerosol that were observed 18 hours after the inhalation. Minimal perivascular interstitial edema, focal aggregates of alveolar macrophages, interstitial mononuclear cell infiltration, thickened alveolar septa and marginal lipoproteinosis were seen in the lungs of those rats. 

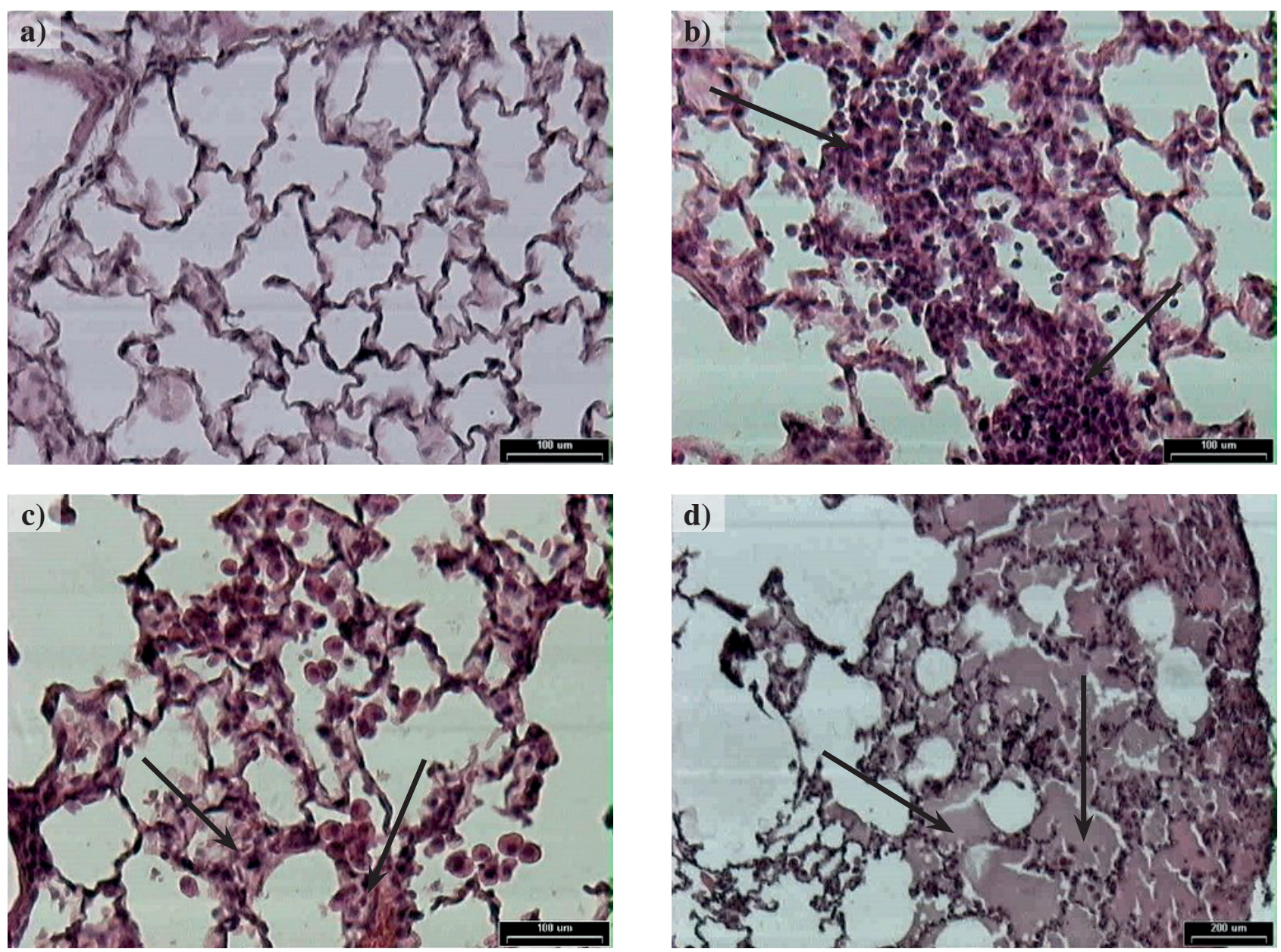

b) Interstitial mononuclear cell infiltrations, thickened alveolar septa, and focal aggregates of alveolar macrophages.

c) Minimal perivascular and interstitial edema. Focal aggregates of alveolar macrophages.

d) Marginal lipoproteinosis and focal aggregates of alveolar macrophages.

H\&E Hematoxylin and eosin staining.

Photo 1. Lungs of the studied rats: a) control group. b-d) group exposed to BAC aerosol at $18 \mathrm{~h}$ after the inhalation

\section{DISCUSSION AND CONCLUSIONS}

Multiple inhalation exposures to ca. $35 \mathrm{mg} / \mathrm{m}^{3}$ BAC aerosol produced severe toxic effects in rats. The animals exposed to BAC aerosol consumed less food and their body weight continued to be lower compared to the controls throughout the experiment.

Similarly to earlier study assessing the pneumotoxic effect of BAC aerosol on laboratory animals, this research revealed a significant influence of the exposure on the level of lung biomarkers. In the majority of cases, a similar trend could be observed in that respect [26]. The adverse effect of exposure to BAC aerosol was not found to be time-dependent. The exposure to BAC aerosol produced a strong pneumotoxic effect manifested by necrosis of the respiratory cells (increased LDH activity) and lung inflammation (higher level of IL-6 and MIP-2) in BALF of the inhalation-challenged rats. Some authors suggest that quaternary ammonium compounds (QAC), such as BAC, may produce proinflammatory changes due to oxidative stress [33-35]. The irritant respiratory effects observed during our 
experiment were attributable probably to the BAC-induced oxidative stress. It is not clear whether the process paves the way for the changes leading finally to the development of asthma, the more so that MMP-9, a marker of severe asthma-like respiratory abnormalities, was at a similar level in the exposed and control animals [36].

On the other hand, the damage to Clara cells, reflected by a decreased concentration of CC16 showing immunosuppressive and anti-inflammatory activity, accompanied by significant increase in the IgE level after exposure to BAC may point to an immuno-inflammatory response [37,38]. The more so that the $\mathrm{CC} 16$ protein released by Clara cells in the respiratory system acts as a controller of the immunosuppressive and anti-inflammatory processes preventing an adverse immune response. It is generally recognized that $\mathrm{CC16}$ controlling the inflammatory process is an equivalent of uteroglobulins [39]. Reduced CC16 concentrations may be indicative of asthmatic changes. Asthmatic patients have been shown to be characterized by lower levels of phospholipase A2, towards which the CC16 protein acts as an inhibitor [40], and reduced levels of CC16 protein [41,42]. A significant increase of the leucocyte count in BALF and numerous focal aggregates of alveolar macrophages observed in the microscopic images of the lungs also point to the immunoinflammatory processes occurring in the lungs of the exposed animals.

BAC exposure induces a massive influx of proteins from blood vessels to the alveolar space, which is manifested by increased total protein concentration in BALF. Increased total protein concentration accompanied by simultaneously reduced $\mathrm{CC} 16$ protein concentrations may point to the damaged integrity of the blood-air barrier [43-46]. Increased total protein levels in the BALF of rats exposed to BAC could be directly responsible for the lack of an immune response in serum. Possibly, during inhalation exposure, a small amount of BAC enters the bloodstream of the rat and most of it is retained in the respiratory tract, where it can be attached to the proteins infiltrating from the bloodstream. Quaternary ammonium compounds are known to have a high affinity to proteins [47]. There is no immediate data analyzing the distribution of BAC under inhalation exposure conditions.

It can be assumed that the intravenous or intra-arterial administration may to some extent illustrate the distribution which occurs during the inhalation exposure. During the experiment on rats, 2 min after the introduction of BAC to the bloodstream by intravenous or intra-arterial injection, it was noted that the BAC concentrations in the lungs were several times higher compared to the levels observed in the liver, kidneys, and even in the blood itself [48]. This suggests that intravascular administration of BAC causes its rapid penetration into the lumen of the lungs, and the lungs are the critical organ. Suming up, inhalation of BAC produced a strong inflammatory response and damage to the blood-air barrier. Decreased serum concentrations of CC16, a protein with immunosuppressive and anti-inflammatory activity, and a parallel increase in the IgE levels in BALF may point to the immuno-inflammatory response of animals exposed by inhalation to BAC aerosol. Histopathological examination of the tissues removed from the rats exposed to BAC shows that pathological changes were found only in the lungs. This indicates that inhalation exposure to BAC results mainly in the damage to the respiratory tract.

\section{ACKNOWLEDGEMENT}

The authors are grateful to Krzysztof Mader for his excellent technical assistance.

\section{REFERENCES}

1. Chen W, Hu J, Zhang Z, Chen L, Xie H, Dong N, et al. Localization and expression of zonula occludins-1 in the rabbit corneal epithelium following exposure to benzalkonium chloride. PLoS One. 2012;7(7):e40893, http://dx.doi.org/10.1371/ journal.pone.0040893. 
2. Clouzeau C, Godefroy D, Riancho L, Rostène W, Baudouin C, Brignole-Baudouin F. Hyperosmolarity potentiates toxic effects of benzalkonium chloride on conjunctival epithelial cells in vitro. Mol Vis. 2012;18:851-63.

3. Dao H Jr, Fricker C, Nedorost ST. Sensitization prevalence for benzalkonium chloride and benzethonium chloride. Dermatitis. 2012;23(4):162-6.

4. Larsen ST, Verder H, Nielsen GD. Airway effects of inhaled quaternary ammonium compounds in mice. Basic Clin Pharmacol Toxicol. 2012;110(6):537-43, http://dx.doi. org/10.1111/j.1742-7843.2011.00851.x.

5. Li C, Song Y, Luan S, Wan P, Li N, Tang J, et al. Research on the stability of a rabbit dry eye model induced by topical application of the preservative benzalkonium chloride. PLoS One. 2012;7(3):e33688, http://dx.doi.org/10.1371/journal. pone. 0033688 .

6. Lee SS, Hong DK, Jeong NJ, Lee JH, Choi YS, Lee AY, et al. Multicenter study of preservative sensitivity in patients with suspected cosmetic contact dermatitis in Korea. J Dermatol. 2012;39(8):677-81, http://dx.doi.org/10.1111/j.13468138.2012.01551.x.

7. Nagai N, Ito Y, Okamoto N, Shimomura Y. [An in vitro evaluation for corneal damages after instillation of eyes drops using rat debrided corneal epithelium: changes in corneal damage of benzalkonium chloride by addition of thickening agent]. Yakugaku Zasshi. 2012;132(7):837-43. Japanese, http://dx.doi.org/10.1248/yakushi.132.837.

8. Paimela T, Ryhänen T, Kauppinen A, Marttila L, Salminen A, Kaarniranta K. The preservative polyquaternium-1 increases cytoxicity and NF-kappaB linked inflammation in human corneal epithelial cells. Mol Vis. 2012;18: 1189-96.

9. Stevens AM, Kestelyn PA, Bacquer D, Kestelyn PG. Benzalkonium chloride induces anterior chamber inflammation in previously untreated patients with ocular hypertension as measured by flare meter: A randomized clinical trial. Acta Ophthalmol. 2012;90(3):e221-4, http://dx.doi.org/10.1111/ j.1755-3768.2011.02338.x.
10. Tabuchi N, Hattori M, Shimizu M, Koide M, Yamazaki H. Evaluation of cytotoxic potential of cored soft contact lenses with adsorbed active ingredients from over-the-counter eye drops. J Toxicol Sci. 2012;37(3):639-43, http://dx.doi. org/10.2131/jts.37.639.

11. Vijayakumar R, Kannan VV, Sandle T, Manoharan C. In vitro antifungal efficacy of biguanides and quaternary ammonium compounds against cleanroom fungal isolates. PDA J Pharm Sci Technol. 2012;66(3):236-42, http://dx.doi. org/10.5731/pdajpst.2012.00866.

12. Wang C, Deng Q, Han D, Zhang L. Effects of benzalkonium chloride and potassium sorbate on airway ciliary activity. ORL J Otorhinolaryngol Relat Spec. 2012;74(3):149-53, http://dx.doi.org/10.1159/000337830.

13. Xu R, Zhang L, Zhao X, Jiang H, Lu Q, Zhong Z, et al. Benzalkonium bromide as a new potential instillation drug for bladder cancer: hypothesis and pilot study. Med Sci Monit. 2011;17(12):HY36-9， http://dx.doi.org/10.12659/ MSM.882110.

14. Jaramillo DE, Arriola A, Safavi K, Chavez de PazLE. Decreased bacterial adherence and biofilm growth on surfaces coated with a solution of benzalkonium chloride. J Endod. 2012;38(6):8215, http://dx.doi.org/10.1016/j.joen.2012.03.012.

15. Zhou N, Xu D, Zhang J, Ma Y, Yuan J, Shen J. Preparation, characterization, and evaluation of a heparin-benzalkonium chloride-graphite oxide/polymethylvinyl siloxane nanocomposite. J Biomed Mater Res A. 2012;100(6):1623-7, http:// dx.doi.org/10.1002/jbm.a.34110.

16. Stanford D, Georgouras K. Allergic contact dermatitis from benzalkonium chloride in plaster of Paris. Contact Dermatitis. 1996;35(6):371-2, http://dx.doi.org/10. 1111/j.1600-0536.1996.tb02427.x.

17. Cox NH. Allergy to benzalkonium chloride simulating dermatomyositis. Contact Dermatitis. 1994;31(1):50, http:// dx.doi.org/10.1111/j.1600-0536.1994.tb01909.x.

18. Van Berkel M, De Wolff FA. Survival after acute benzalkonium chloride poisoning. Hum Toxicol. 1988;7(2):191-3, http://dx.doi.org/10.1177/096032718800700216. 
19. Hitosugi M, Maruyama K, Takatsu A. A case of fata benzalkonium chloride poisoning. Int J Legal Med. 1998;111(5): 262-6, http://dx.doi.org/10.1007/s004140050166.

20. Kilic E, Er N, Alkan A, Ferahbas A. Accidental benzalkonium chloride (zephiran) injection. Oral Surg Oral Med Oral Pathol Oral Radiol Endod. 2011;112(6):e103-5, http:// dx.doi.org/10.1016/j.tripleo.2011.06.004.

21. Marple B, Roland P, Benninger M. Safety review of benzalkonium chloride used as a preservative in intranasal solutions: An overview of conflicting data and opinions. Otolaryngol Head Neck Surg. 2004;130(1):131-41, http://dx.doi. org/10.1016/j.otohns.2003.07.005.

22. Ryan WR, Hawang PH. Safety of a preservative-free acidified saline nasal spray: A randomized, double-blind, placebocontrolled, crossover clinical trial. Arch Otolaryngol Head Neck Surg. 2010;136(11):1099-103, http://dx.doi.org/10.1001/ archoto.2010.179.

23. Preller L, Doekes G, Heederik D, Vermeulen R, Vogelzang PF, Boleij JS. Disinfectant use as a risk factor for atopic sensitization and symptoms consistent with asthma: An epidemiological study. Eur Respir J. 1996;9(7):1407-13, http:// dx.doi.org/10.1183/09031936.96.09071407.

24. Larsen ST, Hansen R, Poulsen OM, Nielsen GD. Adiuvant effect of benzalkonium chloride on the allergen-specific $\mathrm{IgE}$, $\mathrm{IgG1}$ and IgG2a antibody formation in BALB/cJ mice. Basic Clin Pharmacol Toxicol. 2004;95(2):94-6.

25. Larsen ST, Verder H, Nielsen GD. Airway effects of inhaled quaternary ammonium compounds in mice. Basic Clin Pharmacol Toxicol. 2012;110(6):537-43, http://dx.doi. org/10.1111/j.1742-7843.2011.00851.x.

26. Świercz R, Hałatek T, Wąsowicz W, Kur B, Grzelińska Z, Majcherek W. Pulmonary irritation after inhalation exposure to benzalkonium chloride in rats. Int J Occup Med Environ Health. 2008;21(2):157-63, http://dx.doi.org/10.2478/ v10001-008-0020-1.

27. Świercz R, Grzelińska Z, Gralewicz S, Wąsowicz W. Catecholamine levels in the brain of rats exposed by inhalation to benzalkonium chloride. Int J Occup Med Environ
Health. 2009;22(2):107-13, http://dx.doi.org/10.2478/v10001009-0012-9.

28. Dutkiewicz-Wilczyńska J, Tautt J, Roman I. Application of the HPLC method for benzalkonium chloride determination in aerosol preparation. J Pharm Biomed Anal. 2004;34(5):909-20, http://dx.doi.org/10.1016/j. jpba.2003.09.001.

29. Bernat A, Marchandise FX, Depelchin S, Lauwerys R, Sibille Y. Clara cell protein in serum and bronchoalveolar lavage. Eur Respir J. 1992;5(10):1231-8.

30. Hałatek T, Hermans C, Broeckaert F, Wattiez R, Wiedig M, Toubeau G, et al. Quantification of Clara cell protein in rat and mouse biological fluids using a sensitive immunoassay. Eur Respir J. 1998;11(3):726-33.

31. Bergmeyer HU. Methods of Enzymatic Analysis. Weinheim: Verlag Chemie GmbH; 1974. p. 575-80.

32. Habig W, Pabst M, Jacoby W. Glutathione S-transferase: The first step in mercapturic acid formation. J Biol Chem. 1970;249:7130-9.

33. Debbasch C, de Saint Jean M, Pisella PJ, Rat P, Warnet JM, Baudouin C. [Quaternary ammonium cytotoxicity in a human conjunctival cell line]. J Fr Ophtalmol. 1999;22(9): 950-8. French.

34. Debbasch C, Brignole F, Pisella PJ, Warnet JM, Rat P, Baudouin C. Quaternary ammoniums and other preservatives' contribution in oxidative stress and apoptosis on Chang conjunctival cells. Invest Ophthalmol Vis Sci. 2001;42(3): 642-52.

35. Nagamune H, Maeda T, Ohkura K, Yamamoto K, Nakajima M, Kourai H. Evaluation of the cytotoxic effects of bis-quaternary ammonium antimicrobial reagents on human cells. Toxicol In Vitro. 2000;14(2):139-47, http://dx.doi. org/10.1016/S0887-2333(00)00003-5.

36. Lemjabbar H, Gosset P, Lamblin C, Tillie I, Hartmann D, Wallaert B, et al. Contribution of $92 \mathrm{kDa}$ gelatinase/type IV collagenase in bronchial inflammation during status asthmaticus. Am J Respir Crit Care Med. 1999;159(4 Pt 1):1298307, http://dx.doi.org/10.1164/ajrccm.159.4.9708080. 
37. Dierynck I, Bernard A, Roels H, De Ley M. The human Clara cell protein: biochemical and biological characterisation of a natural immunosuppressor. Mult Scler. 1996;1(6):385-7.

38. Shijubo N, Kawabata I, Sato N, Itoh Y. Clinical aspects of Clara cell 10-kDa protein/uteroglobin (secretoglobin 1A1). Curr Pharm Des. 2003;9(14):1139-49, http://dx.doi. org/10.2174/1381612033455026.

39. Mantile G, Miele L, Cordella-Miele E, Singh G, Katayal SL, Mukherjee AB. Human Clara cell 10-kDa protein is counterpart of rabit uteroglobulin. J Biol Chem. 1993;268(27): 20343-51.

40. Bowton DL, Seeds MC, Fasano MB, Goldshmith B, Bass DA. Phospholipase A2 and arachidonate increase in bronchoalveolar lavage fluid after inhaled antigen chalange in asthmatics. Am J Respir Crit Care Med. 1997;155(2): 421-5, http://dx.doi.org/10.1164/ajrccm.155.2.9032172.

41. Laing IA, Hermans C, Bernard A, Burton PR, Goldblatt J, Le Souëf PN. Association between plasma CC16 levels, the A38G polymorphism, and asthma. Am J Respir Crit Care Med. 2000;161(1):124-7, http://dx.doi.org/10.1164/ ajrccm.161.1.9904073.

42. Shijubo N, Itoh Y, Yamaguchi T, Sugaya F, Hirasawa M, Yamada T, et al. Serum levels of Clara cell 10-kDa protein are decreased in patients with asthma. Lung. 1999;177(1):45-52, http://dx.doi.org/10.1007/PL00007626.
43. Bernard AM, Gonzalez-Lorenzo JM, Siles E, Trulillano G, Lauwerys R. Early decrease of serum Clara cell protein in silica-exposed workers. Eur Respir J. 1994;7(11):1932-7.

44. Bernard AM, Roels HA, Buchet JP, Lauwerys RR. Serum Clara cell protein: an indicator of bronchial cell dysfunction caused by tobacco smoking. Environ Res. 1994;66(1):96104, http://dx.doi.org/10.1006/enrs.1994.1047.

45. Hałatek T, Hermans C, Broeckaert F, Wattiez R, Wiedig M, Toubeau G, et al. Quantification of Clara cell protein in rat and mouse biological fluids using a sensitive immunoassay. Eur Resp J. 1998;11(3):726-33.

46. Hałatek T, Trzcinka-Ochocka M, Matczak W, Krajewska B, Wrońska-Nofer T, Rydzyński K. Studies on the relationship between occupational exposure to manganese and serum Clara cell protein levels in shipyard workers. Trace Elem Electrolytes. 2000;17(1):48-53.

47. Adelson L, Sunshine I. Fatal poisoning due to a cationic detergent of the quaternary ammonium compound type. Am J Clin Pathol. 1952;22(7):656-61.

48. Xue Y, Hieda Y, Kimura K, Takayama K, Fujihara J, Tsujino Y. Kinetic characteristics and toxic effects of benzalkonium chloride following intravascular and oral administration in rats. J Chromatogr B Analyt Technol Biomed Life Sci. 2004;811(1):53-8, http://dx.doi.org/10.1016/S15700232(04)00628-2.

This work is available in Open Access model and licensed under a Creative Commons Attribution-NonCommercial 3.0 Poland License - http://creativecommons.org/ licenses/by-nc/3.0/pl/deed.en. 